\title{
A Blood Gene Expression Marker of Early Alzheimer's Disease
}

\author{
Katie Lunnon ${ }^{\mathrm{a}, \mathrm{b}, 1}$, Martina Sattlecker ${ }^{\mathrm{a}, \mathrm{b}, 1}$, Simon J. Furney ${ }^{\mathrm{a}, \mathrm{b}, 1,2}$, Giovanni Coppola ${ }^{\mathrm{c}}$, \\ Andrew Simmons ${ }^{\mathrm{a}, \mathrm{b}}$, Petroula Proitsi ${ }^{\mathrm{a}}$, Michelle K. Lupton ${ }^{\mathrm{a}}$, Anbarasu Lourdusamy ${ }^{\mathrm{a}, \mathrm{b}}$, \\ Caroline Johnston $^{\mathrm{b}}$, Hilkka Soininen ${ }^{\mathrm{d}}$, Iwona Kłoszewska ${ }^{\mathrm{e}}$, Patrizia Mecocci ${ }^{\mathrm{f}}$, \\ Magda Tsolaki $^{\mathrm{g}}$, Bruno Vellas ${ }^{\mathrm{h}}$, Daniel Geschwind ${ }^{\mathrm{c}}$, Simon Lovestone ${ }^{\mathrm{a}, \mathrm{b}}$, Richard Dobson $^{\mathrm{a}, \mathrm{b}, 1}$, \\ Angela Hodges ${ }^{\mathrm{a}, *, 1}$ and On behalf of the AddNeuroMed Consortium \\ a King's College London, Institute of Psychiatry, King's Health Partners Centre for Neurodegeneration \\ Research, London, UK \\ ${ }^{\mathrm{b}}$ NIHR Biomedical Research Centre for Mental Health at South London and Maudsley NHS Foundation Trust \\ and Institute of Psychiatry, King's College London, London, UK \\ ${ }^{\mathrm{c}}$ Program in Neurogenetics, Department of Neurology, David Geffen School of Medicine, \\ University of California at Los Angeles, CA, USA \\ ${ }^{\mathrm{d}}$ Department of Neurology, University of Eastern Finland and Kuopio University Hospital, Kuopio, Finland \\ ${ }^{\mathrm{e}}$ Medical University of Lodz, Lodz, Poland \\ ${ }^{\mathrm{f}}$ Institute of Gerontology and Geriatrics, University of Perugia, Perugia, Italy \\ g 3 rd Department of Neurology, “G. Papanicolaou” Hospital, Aristotle University of Thessaloniki, \\ Thessaloniki, Greece \\ ${ }^{\mathrm{h}}$ INSERM U 558, University of Toulouse, Toulouse, France
}

Accepted 21 August 2012

\begin{abstract}
A marker of Alzheimer's disease (AD) that can accurately diagnose disease at the earliest stage would significantly support efforts to develop treatments for early intervention. We have sought to determine the sensitivity and specificity of peripheral blood gene expression as a diagnostic marker of AD using data generated on HT-12v3 BeadChips. We first developed an $\mathrm{AD}$ diagnostic classifier in a training cohort of $78 \mathrm{AD}$ and 78 control blood samples and then tested its performance in a validation group of $26 \mathrm{AD}$ and 26 control and 118 mild cognitive impairment (MCI) subjects who were likely to have an AD-endpoint. A 48 gene classifier achieved an accuracy of $75 \%$ in the AD and control validation group. Comparisons were made with a classifier developed using structural MRI measures, where both measures were available in the same individuals. In AD and control subjects, the gene expression classifier achieved an accuracy of $70 \%$ compared to $85 \%$ using MRI. Bootstrapping validation produced expression and MRI classifiers with mean accuracies of $76 \%$ and $82 \%$, respectively, demonstrating better concordance between these two classifiers than achieved in a single validation population. We conclude there is potential for blood expression to be a marker for AD. The classifier also predicts a large number of people with MCI, who are likely to develop $\mathrm{AD}$, are more AD-like than normal with $76 \%$ of subjects classified as AD rather than control. Many of these people do not have
\end{abstract}

\footnotetext{
${ }^{1}$ These authors contributed equally.

${ }^{2}$ Present address: The Institute of Cancer Research, London, UK.

*Correspondence to: Angela Hodges, King's College London, Institute of Psychiatry, De Crespigny Park, London, UK. Tel.: +44 207848 0772; Fax: +44 207848 0632; E-mail: angela.k.hodges@ kcl.ac.uk.
} 
overt brain atrophy, which is known to emerge around the time of AD diagnosis, suggesting the expression classifier may detect $\mathrm{AD}$ earlier in the prodromal phase. However, we accept these results could also represent a marker of diseases sharing common etiology.

Keywords: Alzheimer's disease, biomarkers, blood, diagnosis, gene expression pattern analysis, leukocytes, magnetic resonance imaging, mild cognitive impairment

Supplementary data available online: http://dx.doi.org/10.3233/JAD-2012-121363

\section{INTRODUCTION}

Alzheimer's disease $(\mathrm{AD})$ is a common chronic neurodegenerative disorder, accounting for $\sim 60 \%$ of dementia cases. Dementia affects 63 million patients worldwide with numbers set to rise to 114 million by 2050 resulting in dramatic social and economic consequences as our care systems struggle to cope [1]. Although much progress has been made in understanding the molecular pathology of $\mathrm{AD}$, the treatments currently available only temporarily alleviate some symptoms and do not modify pathology. The use of biomarkers for identification of individuals with $\mathrm{AD}$ prior to the appearance of clinical symptoms, the socalled pre-dementia phase of the disease [2], will be essential to the development of drugs for early intervention [3-5]. Furthermore, if sufficiently powered, some biomarkers could be used as part of a screening program for at-risk elderly people [6].

By the time an individual is diagnosed with $\mathrm{AD}$, there is already considerable neuronal cell loss, plaque deposition, and neurofibrillary tangles within the brain $[7,8]$, which may have emerged up to 10 years or more before clinical diagnosis [9-11]. Biomarkers linked to the pathophysiological process in $\mathrm{AD}$ can greatly increase the confidence of concluding a person will have an $\mathrm{AD}$-endpoint even in the pre-dementia phase [12]. Cerebrospinal fluid (CSF) biomarkers such as increased tau and decreased levels of amyloid- $\beta$ $(\mathrm{A} \beta)_{1-42}$ in the CSF correlate with postmortem AD pathology $[13,14]$. These measurements together not only differentiate $\mathrm{AD}$ from normal elderly controls with high accuracy, but can also predict which subjects with mild cognitive impairment (MCI) are likely to progress to $\mathrm{AD}$ within 5 years [15]. However, a lumbar puncture to collect CSF is an invasive procedure, which may not be suitable for use in large-scale trials or for screening populations. Similarly, positron emission tomography (PET) imaging of amyloid burden in the brain correlates with clinical diagnosis of $\mathrm{AD}$, $A \beta$ neuropathology at autopsy $[13,14,16]$, and CSF $A \beta_{1-42}$ levels [17-20]. PET imaging is expensive and impractical to be used in large groups of frail elderly patients and is restricted to specialist centers.

Although $\mathrm{AD}$ is a disease of the brain, it is increasingly accepted that there is communication between the brain and the periphery, and we therefore hypothesize that there will be blood-associated changes detectable in disease which could be used to develop a diagnostic marker. Blood is easily obtainable in frail elderly people and relatively inexpensive to analyze, making it an attractive source for developing a biomarker [21]. Many studies, including those from our own group, have identified AD- and/or MCI-related protein changes in blood plasma using 2DGE/Mass Spectrometry and luminex technology [22-30]. They are undergoing further rounds of testing to establish their validity as the basis for an accurate marker. Companies specializing in AD diagnostics have recently published reports of gene expression changes in blood that are able to distinguish $\mathrm{AD}$ subjects from cognitively normal people. Diagenic ASA published a discovery and validation study consisting of a 96 gene classifier with $72 \%$ accuracy for $\mathrm{AD}$ diagnosis. The marker could also correctly predict the outcome of 7 out of $10 \mathrm{MCI}$ subjects after a 2 year follow-up. Although these numbers are too small to draw firm conclusions about its performance in identifying pre-dementia in MCI subjects, they are encouraging [31, 32]. ExonHit Therapeutics used the additional splice variant discriminatory power of Genome-Wide Splice Arrays to identify a blood expression classifier consisting of 133 genes able to distinguish $\mathrm{AD}$ from normal elderly control subjects with 98\% accuracy [33]. Combining blood measures across different modalities such as proteins, metabolites, and gene expression may further improve biomarker accuracy, although the outcomes of these studies have yet to be reported.

Our aim was to first identify and validate an $\mathrm{AD}$ diagnostic gene expression marker in blood able to distinguish people clinically diagnosed with $\mathrm{AD}$ from normal elderly controls with high sensitivity and specificity. We then sought to evaluate its specificity and sensitivity compared to another marker which 
incorporates structural magnetic resonance imaging (MRI) measures of regional brain atrophy and cortical thickness assessed in the same individuals, using a hypothesis-free approach. To date, the outcome of comparing a gene expression marker of $\mathrm{AD}$ alongside a classifier using measures of brain atrophy has not yet been reported. Classifiers combining measures of cortical thickness and/or regional brain atrophy changes in $\mathrm{AD}$ have previously been shown to very accurately distinguish AD from normal elderly controls [34]. Structural brain changes can also be used to identify people with MCI who will subsequently receive a diagnosis of $\mathrm{AD}$ or experience a more rapid drop in Mini-Mental Status Examination (MMSE) score over time [35, 36]. Structural brain changes generally appear after changes in other modalities such as CSF $\mathrm{A} \beta$ and tau and coincide with neuronal cell loss and the onset of clinical symptoms [11,37].

Individuals with MCI are likely to have an ADendpoint and therefore are more likely to be classified as AD-like rather than normal using an appropriate biomarker. The proportion of people with MCI having prodromal $\mathrm{AD}$ varies between studies as it depends on the method of ascertainment, the criteria for identifying people with MCI, the period of follow-up, and the confirmatory methods for subsequent AD diagnosis. Typical estimates suggest around $\sim 40-75 \%$ of people who have cognitive symptoms consistent with MCI will eventually progress to pathologically confirmed $\mathrm{AD}$ [38-40], with only 5\% "reverting" to normal $[41,42]$ and $\sim 30-55 \%$ developing other dementias [43-45]. We were therefore interested to investigate whether a set of blood gene expression changes found in $\mathrm{AD}$ patients also exist in a MCI population and whether or not there was any distinction between MCI subjects close to receiving a clinical diagnosis of $\mathrm{AD}$ and those who remained MCI within a subsequent two year follow-up period. While our AD diagnostic classifier was adequately powered, we did not have sufficient power to build a separate predictive classifier within our MCI population to determine which subjects would develop AD within two years.

\section{METHODS AND MATERIALS}

\section{Clinical subjects and samples}

Subjects used were from AddNeuroMed, a large cross-European prospective biomarker study (2005-2007) [46, 47]. Informed consent was obtained for all subjects according to the Declaration of Helsinki
(1991) and protocols and procedures were approved by the relevant local ethical committees at each site. Subjects were excluded from the study if they were younger than 65 years, had significant neurological or psychiatric illness other than $\mathrm{AD}$, significant unstable systematic illness or organ failure, or a geriatric depression rating scale score $\geq 4 / 5$ [48].

Normal elderly control subjects were recruited from non-related family members of $\mathrm{AD}$ patients, caregivers' relatives, social centers for the elderly, or GP surgeries and had no evidence of cognitive impairment. A small number of individuals recruited in this way met the MCI criteria detailed below and were therefore included in the MCI cohort for analyses. $\mathrm{AD}$ and MCI subjects were recruited primarily from local memory clinics, and as such the MCI cohort was expected to be composed largely of subjects with a likely AD-endpoint. AD subjects were diagnosed using the National Institute of Neurological and Communicative Disease and Stroke and Alzheimer's disease (NINCDS-ADRDA) [49] and Diagnostic and Statistical Manual of Mental Disorders (DSM-IV) [50] criteria for possible or probable AD. All MCI subjects reported problems with memory, corroborated by an informant, but had normal activities of daily living as specified in the Petersen's criteria for amnestic MCI [51, 52]. MCI subjects scored 0.5 on the total Clinical Dementia Rating Scale or had a memory score of 0.5 or 1 [53]. Within 2 years of the baseline visit, some MCI subjects progressed to a clinical diagnosis of $\mathrm{AD}\left(\mathrm{MCI}_{\mathrm{c}}\right)$, while others remained $\mathrm{MCI}\left(\mathrm{MCI}_{\mathrm{nc}}\right)$. Diagnoses were made by trained researchers following a previously validated protocol [54].

All subjects underwent a structured interview and a battery of neuropsychological assessments including the Mini Mental State Examination (MMSE) [55], Global Deterioration Scale (GDS) [56], and Clinical Dementia Rating Scale (CDR) [53] by trained researchers. Control and MCI subjects were further assessed using the CERAD battery [57]. Detailed information on subject recruitment and assessments can be found in other published studies [46, 47]. Where possible, whole blood samples were collected from each subject for DNA (APOE genotyping) and RNA analyses (gene expression). Consecutive subjects who met MRI inclusion criteria (no claustrophobia, no trauma or surgery which may have left ferromagnetic material in the body, ferromagnetic implants or pacemakers, and the ability to lie still for at least one hour) were invited to undertake an MRI scan until a total of $\sim 20$ subjects per diagnostic group per center were scanned. 


\section{Whole blood RNA extraction}

Venous blood $(2.5 \mathrm{ml})$ was collected into a PAXgene ${ }^{\mathrm{TM}}$ Blood RNA tube (BD) for RNA analysis from subjects who had fasted 2 hours prior to collection. The sample was frozen at $-20^{\circ} \mathrm{C}$ overnight and then transferred to $-80^{\circ} \mathrm{C}$ for long-term storage. Prior to RNA extraction, samples were thawed at room temperature overnight. RNA was extracted using the PAXgene $^{\mathrm{TM}}$ Blood RNA Kit (Qiagen), according to the manufacturer's protocol. The yield and quality of extracted RNA were assessed using the NanoDrop ${ }^{\mathrm{TM}}$ 1000 spectrophotometer (NanoDrop Technologies) and the Agilent 2100 Bioanalyzer (Agilent Technologies) respectively. Only samples with an RNA Integrity Number $\geq 7.0$ were analyzed in this study.

\section{Microarray analysis}

Illumina Human HT-12 v3 Expression BeadChips (Illumina) were used to analyze whole genome transcript expression according to the protocol supplied by the manufacturer in 356 subjects (116 control, $127 \mathrm{MCI}$, and $113 \mathrm{AD}$ ). Samples from subjects who had also undergone an MRI scan or who had subsequently changed their diagnosis from $\mathrm{MCI}$ to $\mathrm{AD}$ within 2 years of the sample being analyzed were prioritized for inclusion. The remaining control, MCI, and $\mathrm{AD}$ subjects were randomly chosen from the cohort available at the time of analysis to provide roughly equal numbers across the three groups with the final number chosen for practical reasons. The beadchips contained 48,803 probes designed using data from RefSeq (Build 36.2, Rel 22) and the UniGene (Build 199) databases. Briefly, the TotalPrep RNA Amplification Kit (Ambion) was used to synthesize cDNA from $200 \mathrm{ng}$ total RNA followed by amplification and biotinylation of cRNA and hybridization. Following hybridization, gene expression values were variance-stabilization transformed and quantile normalized using the R Bioconductor package lumi [58]. A total of 30 chips were excluded from further analysis for a number of reasons including very low BeadChip detection rate, disparity in XIST gene expression gender calling (Illumina probe ID: ILMN_1764573) with recorded gender and/or gender markers derived from SNP chip data from the same individuals or diagnostic re-classification at subsequent visits prior to final data analysis (other than MCI-AD). This left a total of 326 subjects (104 AD, 118 MCI $777 \mathrm{MCI}_{\mathrm{nc}}, 41$ $\mathrm{MCI}_{\mathrm{c}}$ ], and 104 normal elderly control subjects) which were used for classifier development and validation.
Probes that were not expressed in any samples were removed from further analysis, leaving 38,311 probes for classification purposes. Data were adjusted for the independent variables of age, gender, collection site, and RNA quality (RIN).

\section{Neuroimaging}

Highly automated bilateral regional cortical thickness measures from 34 areas and regional brain volume measures from 41 areas totaling 109 measures were obtained from subjects who underwent MRI (Supplementary Table 1). Detailed information about data acquisition, pre-processing, and quality control assessment have been described for this cohort in detail elsewhere [34, 36, 47, 59, 60]. Data from $91 \mathrm{AD}$, $92 \mathrm{MCI}$, and 90 control subjects were included in the analyses.

\section{Diagnostic classifier development}

Using the clinical diagnosis of AD as the diagnostic standard, we developed a classifier containing those measures of blood gene expression able to achieve the greatest sensitivity and specificity in a training cohort. We based our methods on those recommended by the MicroArray Quality Control II (MAQC-II) study [61]. Samples from AD and normal elderly control subjects were randomly divided in to a $75 \%$ training cohort (78 AD, 78 Control; Table 1) and a 25\% independent validation cohort (26 AD, 26 Control; Table 1). Initially a $t$-test was performed in the training cohort to reduce the number of gene expression features, leaving a total of 203 probes with $p$-value $<0.01$ (False discovery rate (FDR)-corrected). These 203 probes were then used to optimize the parameters of a random forest model as the Random Jungle [62] implementation requires. In the optimization procedure, various combinations of the random forest parameters including mTry (number of randomly selected variables) and nTrees (number of trees) were used. In addition, we applied the Meng score as a measure of variable importance [63], backward elimination, and a conditional importance setting of 0.8 , which was kept constant throughout the optimization procedure. The best training result was achieved by a setting of nTrees $=750$ and $m$ Try $=15$, with 50 probes included in the model. These settings and the 50 highest ranked probes were taken further into the final model. The final optimized random forest parameters, 50 highest ranked probes, and all samples in the training cohort were then used 
Table 1

Subject characteristics of the out of bag (training) and validation (test) cohorts used in the development of an AD-Control classifier

\begin{tabular}{|c|c|c|c|c|c|c|}
\hline \multirow{2}{*}{$\begin{array}{l}\text { AD-Control classifier subject } \\
\text { characteristics }\end{array}$} & \multicolumn{2}{|c|}{ Out of bag cohort (Training) } & \multicolumn{4}{|c|}{ Validation cohort (Test) } \\
\hline & Control & $\mathrm{AD}$ & Control & $\mathrm{MCI}_{\mathrm{nc}}$ & $\mathrm{MCI}_{\mathrm{c}}$ & $\mathrm{AD}$ \\
\hline Samples used in analysis & 78 & 78 & 26 & 77 & 41 & 26 \\
\hline Gender (F/M) & $45 / 33$ & $52 / 26$ & $17 / 9$ & $38 / 39$ & $27 / 14$ & $20 / 6$ \\
\hline No. with MRI measures & 67 & 68 & 23 & 73 & 19 & 23 \\
\hline Age in years $( \pm S D)$ & $72.1(6.2)$ & $75.5(6.9)$ & $73.2(7.0)$ & $74.3(5.7)$ & $75.0(6.2)$ & $75.1(6.4)$ \\
\hline Disease duration in years $( \pm S D)$ & N/A & $3.7(2.5)$ & N/A & N/A & N/A & $4.0(2.3)$ \\
\hline $\operatorname{MMSE}( \pm \mathrm{SD})$ & $29.0(1.2)$ & $21.1(4.4)$ & $29.2(1.3)$ & $27.3(1.7)$ & $26.2(2.2)$ & $20.5(5.1)$ \\
\hline ADAS-Cog $( \pm$ SD $)$ & N/A & $23.6(9.4)$ & N/A & N/A & N/A & $22.9(11.2)$ \\
\hline CDR sum of boxes $( \pm \mathrm{SD})$ & $0.1(0.2)$ & $6.4(3.0)$ & $0.1(0.2)$ & $1.3(0.8)$ & $2.1(1.1)$ & $7.0(3.7)$ \\
\hline
\end{tabular}

to build a final random forest model, which was then tested with the independent validation cohort.

In order to allow us to directly compare the predictive power of gene expression with sMRI, we re-developed the expression classifier to include only those samples for which both imaging and gene expression data were available. AD and normal elderly control subjects were divided in to a $75 \%$ training cohort (68 AD, 67 Control; Table 1) and a 25\% independent validation cohort (23 AD, 26 Control; Table 1), maintaining sample groups as before and removing those where only expression data were available in order to achieve a similar sample distribution across training and test cohorts. The reduced training cohort was then used to develop three additional diagnostic models; the first included only sMRI imaging measures, the second included sMRI and gene expression, and the third only gene expression in these samples. For all three models, MCI samples were included with the validation cohort. For imaging classifier development, the 109 structural brain measures derived from MRI were used to optimize the parameters of a random forest model as before with the 20 highest ranked measures taken further in to the final model. For the combined sMRI and gene expression model, 30 imaging and 45 gene expression measures were in the model and for the gene expression model using samples with available sMRI measures, there were 50 measures. The sample workflow, analysis, and model development scheme for classification is illustrated in Fig. 1.

All four diagnostic models were further validated by bootstrapping. First the data set was randomly split into a bootstrap training-set (75\% of samples) and a bootstrap test-set ( $25 \%$ of samples). Each bootstrap training-set was used to build a random forest model, which was subsequently tested in the bootstrap test-set. Thus overall, 200 bootstrap random forest models were generated and tested. The bootstrapping procedure generated a list summarizing and ranking probes based on their importance and predictive power across the 200 bootstrap models.

Using the $\mathrm{R}$ package MVpower (http://cran.rproject.org/web/packages/MVpower/MVpower.pdf) in the above approach, we estimate that for effect sizes of 0.7 and 0.2 we have power of 100 and $80 \%$ respectively to develop a Random Forest classifier with 203 features and 50 probes based on sample sizes of 78 in each group. Our effect size of 0.7 was based on differences between cases and controls in the selected 203 features, 0.2 was chosen as a conservative lower limit.

\section{RESULTS}

Performance of diagnostic classifier in distinguishing AD from normal elderly control subjects

We sought to identify and evaluate a blood gene expression diagnostic classifier of AD that could distinguish people with $\mathrm{AD}$ from normal elderly control subjects. We found 48 genes, represented by 50 Illumina probes selected through backward elimination of 203 probes identified by $t$-tests (Supplementary Table 2; available online: http://www.j-alz.com/ issues/33/vol33-3.html\#supplementarydata03), and achieved the highest "out of bag" accuracy in our training cohort. The 50 probes along with their Meng score of relative importance within the classifier are listed in Table 2. When this AD-Control classifier was applied to the independent validation group of samples, it was able to correctly classify $39 / 52$ subjects $(75.0 \%$ accuracy), of which $21 / 26$ AD subjects were correctly classified $(80.8 \%$ sensitivity) and $18 / 26$ normal elderly control subjects were correctly excluded (69.2\% specificity) (Table 3A), achieving a positive predictive value (PPV) of $72.4 \%$ and negative 
1. Sample workflow:

AddNeuroMed Participants:

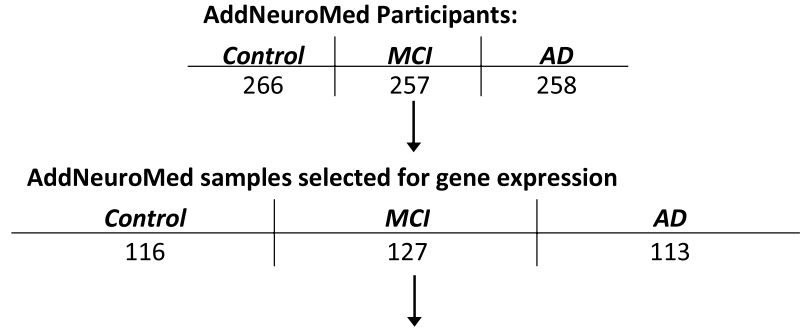

Gene expression samples remaining after quality control:

\begin{tabular}{|c|c|c|c|c|c|c|}
\hline sMRI measures & Control & $\mathrm{MCl}$ & $A D$ & & & \\
\hline Available & 90 & 92 & 91 & & & \\
\hline Not available & 14 & 26 & 13 & & & \\
\hline \multicolumn{2}{|c|}{ raining cohort (75\%): } & \multicolumn{5}{|c|}{ Validation cohort (25\%): } \\
\hline Control & $A D$ & $s M R I$ & Contro & MCIn & MClc & $A D$ \\
\hline 67 & 68 & Available & 23 & 19 & 73 & 23 \\
\hline 11 & 10 & Not available & 3 & 22 & 4 & 3 \\
\hline
\end{tabular}

\section{Use of training cohort for classifier development:}

Classifiers:

-All expression data (all samples)

-sMRI data

- Expression and sMRI data

- Expression data (only samples with available sMRI measures)

\begin{tabular}{|l|}
\hline Feature reduction: \\
A. 203 probes remain after t-test ( $p<0.01$, \\
adjusted) \\
B. no feature reduction for sMRI measures \\
C. Probes as in A, sMRI measures as in B \\
D. Probes as in A \\
\begin{tabular}{|l|}
\hline Random Forest model optimization (same for all \\
classifiers): \\
- mTry parameter \\
- Number of trees \\
- Backwards elimination \\
- Meng score for variable importance estimation \\
\hline
\end{tabular} \\
\hline $\begin{array}{l}\text { Result: } \\
\text { Final model selection based on out of bag error } \\
\text { (for all four classifiers) }\end{array}$ \\
\hline
\end{tabular}

\section{Final validation of classifiers:}

Test of final model with validation cohort: -All expression data (all samples)

-sMRI data

- Expression and SMRI data

- Expression data (only samples with available sMRI measures)

Result:
-Accuracy for all classifier
-Cohen's kappa coefficient for inter-rater
agreement

\section{Bootstrapping:}

Repeat the following steps 200 times:

-Re-sampling (bootstrap training cohort and bootstrap validation cohort)

-Gene expression, 203 probes as previously filtered by t-test; all 109 sMRI measures -Use bootstrap training cohorts and backward elimination and Meng score estimation) to build model

-Test models with bootstrap test set

Result:
-200 classifier accuracies reflecting variation in
population

Fig. 1. Sample flow, model development, and model validation scheme for classification. Samples with a minimum RNA integrity number of 7 were selected from AddNeuroMed participants, with priority given to those who had undergone MRI scans and MCI subjects known to have converted from MCI to AD. The remaining control, MCI, and AD subjects were randomly chosen from available samples to provide approximately equal numbers across the three groups. When generating the AD-Control classifier, AD and Control samples were randomly categorized as training (out of bag) $(75 \%)$ or validation $(25 \%)$ from samples passing quality control. Samples from all MCI subjects were examined as part of the validation cohort to assess how they were categorized relative to AD and normal elderly control subjects. Each classifier was developed in the training cohort and then tested in the validation cohorts to generate a final probe (gene) or imaging measure list along with a measure of accuracy, sensitivity, and specificity. Finally data underwent bootstrapping, whereby in each bootstrap iteration (total of 200) a new development and validation set was drawn from the complete data set used for each model. In each round of bootstrapping, the training set was used to build a classification model, which was then assessed with the validation set. This method gives a range of classifier accuracies, reflecting variation in the population, and allowing an additional assessment to the traditional independent test set approach. 
Table 2

The 50 Illumina probes (48 genes) that best classify AD from control samples in the training cohort

\begin{tabular}{|c|c|c|c|c|}
\hline Gene symbol & Illumina probe & Meng score $^{\mathrm{a}}$ & $q$-value ${ }^{\mathrm{b}}$ & Bootstrap count ${ }^{\mathrm{c}}$ \\
\hline RPS27A & ILMN_2048326 & $1.87 \mathrm{E}-02$ & $2.11 \mathrm{E}-05$ & 200 \\
\hline CHMP4A & ILMN_1715607 & $1.71 \mathrm{E}-02$ & 4.10E-03 & 200 \\
\hline SFRS17A & ILMN_1807737 & $1.68 \mathrm{E}-02$ & $1.97 \mathrm{E}-03$ & 198 \\
\hline POMP & ILMN_1693287 & $1.67 \mathrm{E}-02$ & $3.62 \mathrm{E}-05$ & 147 \\
\hline C5ORF41 & ILMN_2195821 & $1.66 \mathrm{E}-02$ & $9.41 \mathrm{E}-05$ & 142 \\
\hline FTHL7 & ILMN_2234016 & $1.65 \mathrm{E}-02$ & $2.28 \mathrm{E}-03$ & 67 \\
\hline LOC401206 & ILMN_1792528 & $1.59 \mathrm{E}-02$ & $3.62 \mathrm{E}-05$ & 115 \\
\hline AK2 & ILMN_1716053 & $1.58 \mathrm{E}-02$ & 2.34E-03 & 161 \\
\hline UQCRB & ILMN_1759453 & $1.55 \mathrm{E}-02$ & $3.64 \mathrm{E}-03$ & 200 \\
\hline LOC653505 & ILMN_1776260 & $1.55 \mathrm{E}-02$ & 4.95E-05 & 134 \\
\hline PGS1 & ILMN_2075051 & $1.51 \mathrm{E}-02$ & $2.34 \mathrm{E}-03$ & 58 \\
\hline NRBP2 & ILMN_1733248 & $1.50 \mathrm{E}-02$ & $1.85 \mathrm{E}-03$ & 197 \\
\hline UTP14A & ILMN_2095820 & $1.47 \mathrm{E}-02$ & 2.34E-03 & 57 \\
\hline DICER1 & ILMN_1772692 & $1.46 \mathrm{E}-02$ & 4.32E-04 & 180 \\
\hline RPL36AL & ILMN_2189936 & $1.44 \mathrm{E}-02$ & $3.62 \mathrm{E}-05$ & 200 \\
\hline ATP5EP2 & ILMN_2225887 & $1.42 \mathrm{E}-02$ & $5.76 \mathrm{E}-03$ & 145 \\
\hline SIRPG & ILMN_1771801 & $1.39 \mathrm{E}-02$ & $2.34 \mathrm{E}-03$ & 20 \\
\hline LSM3 & ILMN_2229242 & $1.36 \mathrm{E}-02$ & $8.15 \mathrm{E}-03$ & 200 \\
\hline APBB3 & ILMN_2320513 & $1.33 \mathrm{E}-02$ & 2.89E-03 & 177 \\
\hline MRPL51 & ILMN_2097421 & $1.32 \mathrm{E}-02$ & 2.19E-07 & 200 \\
\hline RELL2 & ILMN_1652540 & $1.30 \mathrm{E}-02$ & $5.10 \mathrm{E}-03$ & 187 \\
\hline CETN2 & ILMN_1695645 & $1.29 \mathrm{E}-02$ & $2.11 \mathrm{E}-05$ & 195 \\
\hline PWP1 & ILMN_1743049 & $1.18 \mathrm{E}-02$ & $5.07 \mathrm{E}-03$ & 81 \\
\hline KIAA0146 & ILMN_1887174 & $1.15 \mathrm{E}-02$ & $7.55 \mathrm{E}-04$ & 100 \\
\hline LOC388720 & ILMN_1754990 & $1.14 \mathrm{E}-02$ & $2.12 \mathrm{E}-04$ & 101 \\
\hline CIP29 & ILMN_1680967 & $1.11 \mathrm{E}-02$ & $5.41 \mathrm{E}-03$ & 191 \\
\hline LOC388621 & ILMN_1677262 & $1.11 \mathrm{E}-02$ & $4.75 \mathrm{E}-03$ & 139 \\
\hline SFRS17A & ILMN_2117716 & $1.10 \mathrm{E}-02$ & 4.87E-04 & 182 \\
\hline PCBP1 & ILMN_1673215 & $1.09 \mathrm{E}-02$ & 4.23E-04 & 100 \\
\hline ATP5J2 & ILMN_2310621 & $1.08 \mathrm{E}-02$ & $3.09 \mathrm{E}-05$ & 65 \\
\hline H2AFY & ILMN_2373495 & $1.07 \mathrm{E}-02$ & $6.30 \mathrm{E}-03$ & 163 \\
\hline COX17 & ILMN_2187718 & $1.07 \mathrm{E}-02$ & $1.21 \mathrm{E}-05$ & 5 \\
\hline IDS & ILMN_1758626 & $1.07 \mathrm{E}-02$ & $2.34 \mathrm{E}-03$ & 162 \\
\hline SHFM1 & ILMN_2128128 & $1.07 \mathrm{E}-02$ & $2.80 \mathrm{E}-04$ & 173 \\
\hline LOC651064 & ILMN_1782417 & $1.03 \mathrm{E}-02$ & $6.09 \mathrm{E}-03$ & 53 \\
\hline STX16 & ILMN_1741942 & $9.95 \mathrm{E}-03$ & $1.91 \mathrm{E}-03$ & 160 \\
\hline GDPD1 & ILMN_2106265 & $9.93 \mathrm{E}-03$ & $4.88 \mathrm{E}-03$ & 179 \\
\hline C6ORF166 & ILMN_2148847 & $9.85 \mathrm{E}-03$ & $5.31 \mathrm{E}-03$ & 27 \\
\hline ING3 & ILMN_2237746 & $9.83 \mathrm{E}-03$ & $5.42 \mathrm{E}-03$ & 158 \\
\hline CACNA2D4 & ILMN_1696317 & $9.61 \mathrm{E}-03$ & 7.73E-03 & 47 \\
\hline PLEK & ILMN_1795762 & $9.22 \mathrm{E}-03$ & $2.84 \mathrm{E}-03$ & 3 \\
\hline NDUFA1 & ILMN_1784286 & $9.04 \mathrm{E}-03$ & $2.45 \mathrm{E}-06$ & 198 \\
\hline CDKN1B & ILMN_1722811 & 7.90E-03 & 7.93E-03 & 199 \\
\hline RGS19 & ILMN_1677085 & 7.62E-03 & $5.48 \mathrm{E}-03$ & 165 \\
\hline RPS27A & ILMN_1755883 & 7.61E-03 & 2.77E-04 & 180 \\
\hline LOC731640 & ILMN_1661174 & 7.41E-03 & 8.33E-03 & 66 \\
\hline AHSA1 & ILMN_1703617 & $6.98 \mathrm{E}-03$ & $1.74 \mathrm{E}-03$ & 58 \\
\hline $\mathrm{BXDC1}$ & ILMN_1664167 & $6.43 \mathrm{E}-03$ & 4.29E-04 & 0 \\
\hline KARS & ILMN_1777584 & $5.54 \mathrm{E}-03$ & $2.56 \mathrm{E}-03$ & 5 \\
\hline UBE2G1 & ILMN_1814465 & $-4.62 \mathrm{E}-04$ & $1.74 \mathrm{E}-03$ & 105 \\
\hline
\end{tabular}

${ }^{\mathrm{a}}$ An estimate of variable (probe) importance in the AD versus Control classifier Random Forest model. ${ }^{\mathrm{b}} q$-value from a $t$-test comparing AD and control samples. ${ }^{\mathrm{c}}$ The number of times each probe from the out of bag classifier appeared in the 200 bootstrap iterations.

predictive value (NPV) of 78.3\%. As APOE 4 dosage is a known risk factor for developing $\mathrm{AD}$, we repeated the model creation step including the APOE 4 genotype in the list of attributes. During backward elimination, we found this attribute was removed in the early rounds of the iterative process and therefore excluded it from further analysis. As the accuracy of a classifier varies depending on the population sampled, we bootstrapped the sampled population 200 times to assess the accuracy of the 203 probes identified 
Table 3

Classifiers' performance in out of bag and validation data sets following Random Forests modeling, implemented in Random Jungle

\begin{tabular}{|c|c|c|c|c|c|c|c|c|}
\hline \multirow{2}{*}{$\begin{array}{l}\text { (A) Performance of AD-Control classifier } \\
\text { in } \mathrm{AD} \text { and Control samples }\end{array}$} & \multicolumn{2}{|c|}{ Accuracy } & \multicolumn{2}{|c|}{ Sensitivity } & \multicolumn{2}{|c|}{ Specificity } & \multirow[t]{2}{*}{$\mathrm{PPV}(\%)$} & \multirow[t]{2}{*}{ NPV (\%) } \\
\hline & $\begin{array}{c}\text { Total } \\
\text { correctly } \\
\text { classified }\end{array}$ & $\%$ & $\begin{array}{c}\mathrm{AD} \\
\text { correctly } \\
\text { classified }\end{array}$ & $\%$ & $\begin{array}{l}\text { Control } \\
\text { correctly } \\
\text { classified }\end{array}$ & $\%$ & & \\
\hline$\overline{\mathrm{AD}-\text { Control training cohort }}{ }^{\text {(expression) }}$ & $128 / 156$ & 82.1 & $68 / 78$ & 87.2 & $60 / 78$ & 76.9 & 79.7 & 85.7 \\
\hline AD-Control validation cohort (expression) & $39 / 52$ & 75.0 & $21 / 26$ & 80.8 & $18 / 26$ & 69.2 & 72.4 & 78.3 \\
\hline AD-Control validation cohort ${ }^{(\text {expression }+ \text { imaging })}$ & $36 / 46$ & 78.3 & $19 / 23$ & 82.6 & $17 / 23$ & 73.9 & 76.0 & 81.0 \\
\hline AD-Control validation cohort (imaging) & $39 / 46$ & 84.8 & $20 / 23$ & 87.0 & $19 / 23$ & 82.6 & 83.3 & 86.4 \\
\hline \multirow[t]{2}{*}{ AD-Control validation cohort (expression [in imaging subset]) } & $32 / 46$ & 69.6 & $16 / 23$ & 69.6 & $16 / 23$ & 69.6 & 69.6 & 69.6 \\
\hline & Mean & $95 \% \mathrm{CI}$ & Mean & $95 \% \mathrm{CI}$ & Mean & $95 \% \mathrm{CI}$ & & \\
\hline AD-Control bootstrapping ${ }^{\mathrm{a}}$ (expression) & 78.2 & $77.4-79.0$ & 79.6 & $78.4-80.8$ & 76.8 & $75.7-77.9$ & & \\
\hline AD-Control bootstrapping a (expression + imaging) & 84.0 & $83.3-84.7$ & 84.4 & 83.4-85.4 & 83.5 & 82.4-84.6 & & \\
\hline AD-Control bootstrapping ${ }^{\mathrm{a} \text { (imaging) }}$ & 82.0 & $81.3-82.7$ & 80.0 & 78.9-81.1 & 84.0 & $82.9-85.1$ & & \\
\hline AD-Control bootstrapping a (expression [in imaging subset]) & 76.0 & $75.1-76.9$ & 76.4 & $75.1-77.7$ & 75.4 & $74.1-76.7$ & & \\
\hline \multirow{2}{*}{$\begin{array}{l}\text { (B) Performance of AD-Control classifier } \\
\text { in MCI samples }\end{array}$} & \multicolumn{2}{|c|}{ Accuracy } & \multicolumn{2}{|c|}{ Sensitivity } & \multicolumn{2}{|c|}{ Sensitivity } & & \\
\hline & $\begin{array}{l}\text { MCI classified } \\
\text { as AD-like }\end{array}$ & $\%$ & $\begin{array}{l}\mathrm{MCI}_{\mathrm{c}} \text { classified } \\
\text { as AD-like }\end{array}$ & $\%$ & $\begin{array}{l}\text { MCI }_{\text {nc }} \text { classified } \\
\text { as AD-like }\end{array}$ & $\%$ & & \\
\hline MCI cohort (expression) & $90 / 118$ & 76.3 & $32 / 41$ & 78.0 & $58 / 77$ & 75.3 & & \\
\hline MCI cohort (expression + imaging) & $57 / 92$ & 67.8 & $15 / 19$ & 78.9 & $42 / 73$ & 57.5 & & \\
\hline MCI cohort ${ }^{\text {(imaging) }}$ & $45 / 92$ & 48.9 & $12 / 19$ & 63.2 & $33 / 73$ & 45.2 & & \\
\hline \multirow[t]{2}{*}{ MCI cohort (expression [in imaging subset]) } & $64 / 92$ & 69.6 & $16 / 19$ & 84.2 & $48 / 73$ & 65.8 & & \\
\hline & Mean & $95 \% \mathrm{CI}$ & Mean & $95 \% \mathrm{CI}$ & Mean & $95 \% \mathrm{CI}$ & & \\
\hline MCI bootstrapping a (expression) & 86.0 & $84.6-87.4$ & 87.2 & $85.9-88.5$ & 85.5 & $84.0-87.0$ & & \\
\hline MCI bootstrapping a (expression + imaging) & 61.5 & $61.1-61.9$ & 83.6 & $79.8-87.4$ & 55.8 & $55.4-56.2$ & & \\
\hline MCI bootstrappinga (imaging) & 47.2 & $46.8-47.6$ & 71.0 & $70.0-72.0$ & 41.0 & $40.6-41.4$ & & \\
\hline MCI bootstrapping ${ }^{\mathrm{a}}$ (expression [in imaging subset]) & 70.4 & $69.8-71.0$ & 89.0 & $88.4-89.7$ & 65.6 & $65.0-66.2$ & & \\
\hline
\end{tabular}

${ }^{a}$ For bootstrapped data, the mean value and $95 \%$ confidence interval (95\% CI), measured over 200 models is shown. 

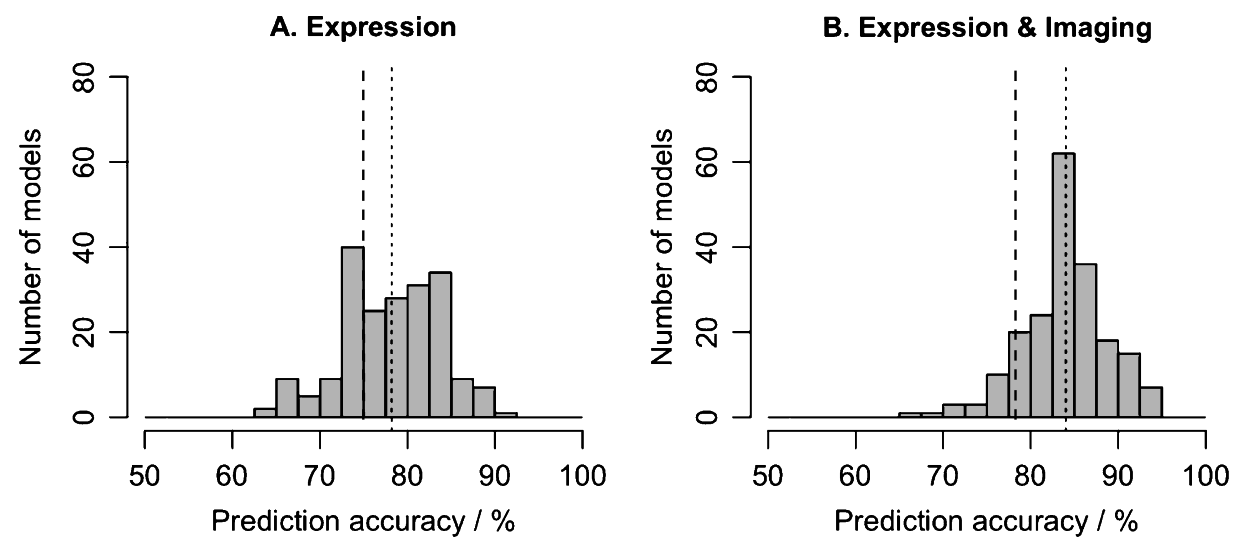

C. Imaging
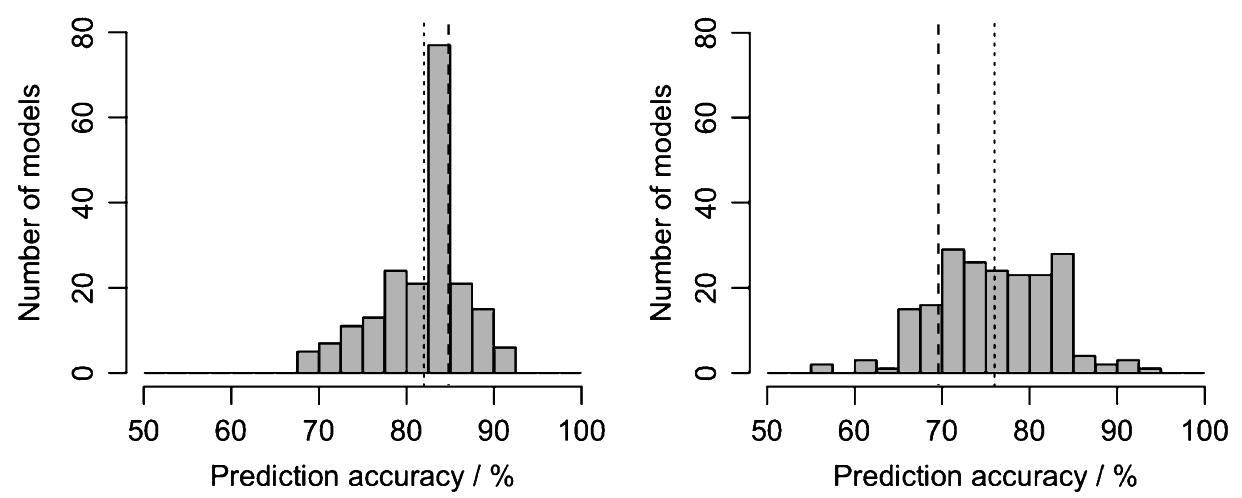

$\begin{array}{ll}- & \text { Accuracy of "out of bag" classifier in validation cohort } \\ ---- & \text { Mean accuracy of bootstrap classifiers }\end{array}$

Fig. 2. Bootstrap results for AD-Control classifier in classifying AD and Control samples. The graphs demonstrate the mean accuracy of the classifier measured from bootstrapping (short dashed line) and the accuracy measured using the "out of bag" classifier in the validation cohort (long dashed line). Results are shown for (A) expression classifier alone, (B) expression and imaging classifiers combined, (C) imaging classifier alone, and (D) expression classifier alone in the subset of individuals with sMRI measures.

by $t$-tests in the original training cohort. Using this method, the accuracy of the expression classifiers was slightly higher than we had estimated, with a mean accuracy of $78.2 \%$ (95\% CI, 77.4-79.0\%), a sensitivity of $79.6 \%$ (95\% CI, 78.4-80.8\%), and a specificity of $76.8 \%$ (95\% CI, 75.7-77.9\%) (Fig. 2A; Table 3A).

Structural MRI is able to accurately detect subtle changes in the thickness or volume of particular brain areas that occur during AD pathogenesis and is believed to be associated with the onset of neuronal dysfunction and cell loss. We first investigated the power of sMRI to classify the AD and control subjects using 68 local cortical thickness and 41 brain volume MRI measures collected in a subset of our cohort around the time of blood sampling [34, 36, 59, 60] (Supplementary Table 1). As six patients used in our expression validation cohort did not have neuroimag- ing measures, we initially re-evaluated our 203 probes on this subset of 46 patients. Accuracy, sensitivity, specificity, PPV, and NPV were all 69.6\%, indicating a small drop in performance in this subgroup. However, when bootstrapping, the mean accuracy achieved was $76.0 \%$ accuracy $(95 \% \mathrm{CI}, 75.1-76.9 \%)$, with a sensitivity of $76.4 \%$ (95\% CI, 75.1-77.7\%) and specificity of $75.4 \%$ (95\% CI, 74.1-76.7\%) (Fig. 2D; Table 3A), values similar to that observed in the larger expression cohort (Fig. 2A; Table 3A) and demonstrating that bootstrapping is important for assessing the true variation in accuracy within a population. The sMRI measures correctly classified 39 people out of 46 tested in the validation cohort ( $84.8 \%$ accuracy), corresponding to 20 out of $23 \mathrm{AD}$ subjects correctly included ( $87.0 \%$ sensitivity), and 19 out of 23 control subjects correctly excluded ( $82.6 \%$ specificity) (Table $3 \mathrm{~A})$. The mean accuracy from bootstrapping was lower $(82.0 \%$; 
95\% CI, 81.3-82.7\%), due to fewer AD subjects being correctly classified over the 200 models $(80.0 \%$ mean sensitivity; 95\% CI, 78.9-81.1\%), although specificity was slightly improved $(84.0 \%$ specificity; $95 \%$ CI, 82.9-85.1\%) (Fig. 2C; Table 3A). The Kappa coefficient was 0.31 ( $p$-value $<0.05$ ) demonstrating good agreement between the imaging and expression classifiers.

Combining the expression and imaging measures resulted in a small increase in mean accuracy following bootstrapping (84.0; 95\% CI, 83.3-84.7\%) (Fig. 2B; Table 3A). This was due to a small increase in the number of AD subjects being correctly classified (84.4\% mean sensitivity; 95\% CI, 83.4-85.4\%), than achieved with imaging or expression alone.

\section{Performance of diagnostic classifier in MCI subjects}

To evaluate whether our diagnostic blood gene expression classifier could be an early marker of cognitive dysfunction, we tested it in 118 MCI subjects to see how many subjects would be classified as "ADlike" rather than as controls, and whether there was any preference for subjects who subsequently received an $\mathrm{AD}$ diagnosis within 2 years $\left(\mathrm{MCI}_{\mathrm{c}}\right)$ compared to those had not received an $\mathrm{AD}$ diagnosis $\left(\mathrm{MCI}_{\mathrm{nc}}\right)$, but nevertheless were likely to have an $\mathrm{AD}$-endpoint. It categorized the majority of MCI subjects as "AD-like" (90/118 subjects, $76.3 \%$ ) rather than as controls, which corresponded to $32 / 41 \mathrm{MCI}_{\mathrm{c}}(78.0 \%)$ and $58 / 77 \mathrm{MCI}_{\mathrm{nc}}$ (75.3\%) (Table 3B). When bootstrapped, the mean accuracy was higher $(86.0 ; 95 \%$ CI, 84.6-87.4\%), with a similar proportion of $\mathrm{MCI}_{\mathrm{nc}}$ and $\mathrm{MCI}_{\mathrm{c}}$ being classified as AD-like (mean 87.2 and $85.5 \%$, respectively) (Fig. 3A; Table 3B).

Although there were only a limited number of $\mathrm{MCI}_{\mathrm{c}}$ subjects with sMRI scans available for analysis (only 19 subjects with imaging compared to 41 available with expression), we assessed the performance of our diagnostic expression classifier in the $\mathrm{MCI}_{\mathrm{c}}$ and $\mathrm{MCI}_{\mathrm{nc}}$ groups separately and compared this to the performance with sMRI based models in 92 individuals for which sMRI and expression data were both available. Of the 92 people with MCI, 64 were classified as AD-like (69.6\%) using the expression classifier, corresponding to $48 / 73 \mathrm{MCI}_{\mathrm{nc}}(65.8 \%)$ and $16 / 19 \mathrm{MCI}_{\mathrm{c}}$ $(84.2 \%)$. When the sample cohort was bootstrapped, the mean accuracy was $70.4 \%$ (95\% CI, 69.8-71.0\%). Compared to the whole expression cohort, accuracy in this subpopulation was lower and while the mean sensitivity in classifying $\mathrm{MCI}_{\mathrm{c}}$ was high $(89.0 \%$; $95 \% \mathrm{CI}$,
88.4-89.7\%), the mean sensitivity to classify $\mathrm{MCI}_{\mathrm{nc}}$ as AD-like was far lower than in the whole population analyzed (65.6\%; 95\% CI, 65.0-66.2\%) (Fig. 3D; Table 3B).

sMRI alone appeared less able to classify $\mathrm{MCI}_{\mathrm{c}}$ as "AD-like" (63.2\%) compared to the expression classifier (84.2\%), classifying only 12 out of 19 patients as AD-like, suggesting imaging is not as sensitive at identifying potential prodromal $\mathrm{AD}$ subjects compared to the expression classifier, even when these individuals were within two years of receiving an $\mathrm{AD}$ diagnosis. In the $\mathrm{MCI}_{\mathrm{nc}}$ group, the imaging classifier was no better than chance $(33 / 73 ; 45.2 \%)$ at classifying individuals as "AD-like" or control, whereas the expression classifier identified more "AD-like" individuals in the $\mathrm{MCI}_{\mathrm{nc}}$ population $(65.8 \%)$ (Table 3B).

\section{DISCUSSION}

We have shown that there may be potential in using blood expression as a diagnostic classifier for AD. Specifically, we have identified 48 genes (50 probes) which can distinguish between $\mathrm{AD}$ and normal elderly control subjects with an accuracy of $75 \%$ in a validation cohort. This performance is consistent with previously reported accuracies using blood gene expression measures [31-33] and is similar to other single or multivariate classifiers incorporating measures from CSF and/or neuroimaging [64-68].

No marker would be expected to achieve perfect accuracy when tested in a population of people clinically diagnosed with $\mathrm{AD}$ as $\mathrm{AD}$ is a very heterogeneous disease with symptoms similar to other dementias and is therefore not always correctly diagnosed by a set of clinical symptoms alone. Clinical diagnosis generally achieves $80-90 \%$ accuracy against a postmortem AD diagnosis [54]. Furthermore, some of the pathologically relevant changes detected by a marker may occur before symptoms emerge in apparently normal people, leading to their apparent misclassification. Amyloid deposition is not only possible to detect in people with MCI, but is also present in 20-40\% of cognitively normal elderly people, up to 10 years before $\mathrm{AD}$ diagnosis $[11,14,15,20,69-75]$. Some of the normal elderly subjects in our study displayed blood expression changes characteristic of people with AD. Although speculative, this may not be misclassification by the marker, but could instead represent subtle peripheral changes occurring in pre-clinical disease.

Of the 39 genes included in the classifier with known function, eight are associated with mitochondrial 

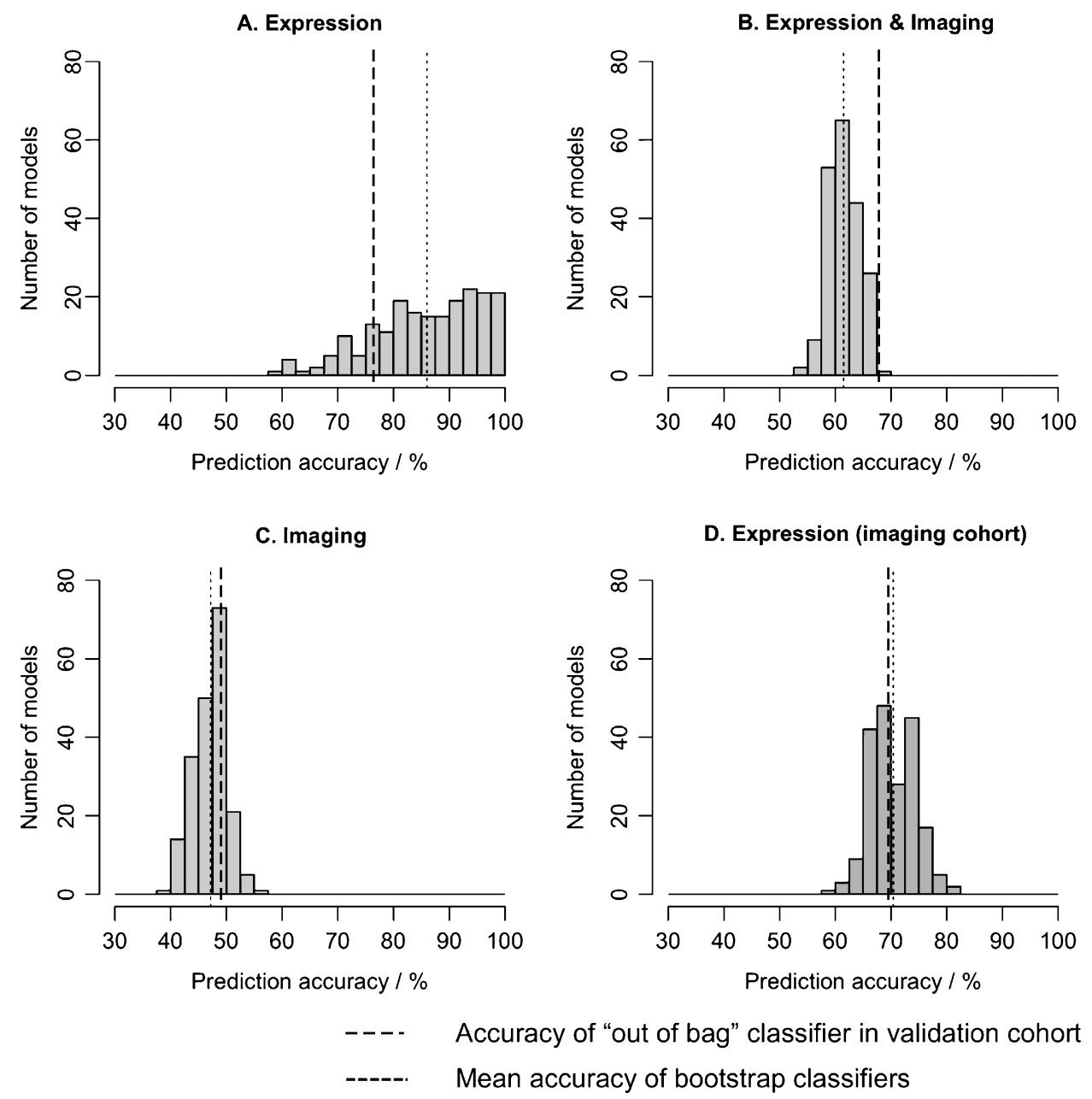

Fig. 3. Bootstrap results for the AD-Control classifier in classifying MCI samples. The graphs demonstrate the mean accuracy of the classifier measured from bootstrapping (short dashed line), and the accuracy measured with the "out of bag" classifier in the validation cohort (long dashed line). Results are shown for (A) expression classifier alone, (B) expression and imaging classifiers combined, (C) imaging classifier alone, and (D) expression classifier alone in the subset of individuals with sMRI measures.

activity and oxidative phosphorylation including subunits of the electron transport chain or constituents of mitochondrial ribosomes and 12 are involved in translation. Changes in the expression of genes associated with these processes in AD blood was recently described in detail by us [76] and genes involved in these processes are enriched in other AD gene expression classifiers [32, 33]. These processes are also significantly altered in the brains of people with $\mathrm{AD}$ [77-80], which may represent a common response to the same disease-associated signal(s).

There are a number of limitations to this study, namely the sample size for validation and the lack of additional cohorts to further test the classifier. By performing power calculations using the MVPower $\mathrm{R}$ package, we have shown that our sample size has $80 \%$ power with a conservative effect size estimate of 0.2 and $100 \%$ with an effect size of 0.7 as derived from our data. We have addressed the second issue by applying a robust bootstrapping approach, considered by the community to be the most appropriate approach for evaluating a classifier when a second cohort is unavailable [61]. When new datasets become available to us we will be able to test the performance of our classifier in additional samples. We are confident that the findings will replicate, as the predictive genes are known to be AD-related and these processes have been previously identified in AD classifier studies, as described above.

In order to further explore the performance of the blood expression classifier we developed, we analyzed measures of cortical thickness and local 
brain atrophy determined by MRI where available in the same subjects. Measures of brain atrophy correlate with the severity of cognitive impairment and rates of neuronal and synaptic loss in $\mathrm{AD}[60$, $81,82]$. Our best neuroimaging classifier achieved an accuracy of $85 \%$, similar to what has been reported previously $[34,83]$ and only slightly better than the blood expression classifier. Overall these results add weight to the diagnostic validity of using the blood expression classifier we have developed for diagnosing $\mathrm{AD}$ independently of information provided by other methods such as structural MRI measures. However, further evaluation is needed to validate its performance in independent samples.

While a diagnostic marker to back up a clinical diagnosis of $\mathrm{AD}$ is of value, an arguably more important goal is to improve the likelihood of identifying people with prodromal AD as early as possible in the course of their disease, which will reduce variability in clinical trials and allow recruitment and eventually treatments to begin as close as possible to disease onset before irreversible brain changes occur. This is an enormous challenge as there are no obvious transition points to AD. Markers are likely to be far more sensitive at picking up early disease-relevant changes than phenotypic measures. In practice, it is likely that multimodal markers will be used in combination to build up a profile of disease likelihood for each individual. One of the earliest indications of AD pathology that have been reported is decreased CSF $A \beta_{1-42}$ levels and increased brain $A \beta$ plaque deposition, which can be observed in pre-clinical disease in some individuals. The connection between CSF $A \beta_{1-42}$ and $A D$ pathology is well established, with CSF $A \beta_{1-42}$ correlating with postmortem plaque [14], tangle number [84], aggregate deposition evaluated by PIB-PET and FDDNP-PET [20], and atrophy measured by CT [85].

Pathophysiological changes emerging in the course of $\mathrm{AD}$ are believed to be associated with a dynamic temporal sequence of changes in the brain and other biological fluids $[12,86]$. Our data adds weight to the body of evidence suggesting there may be potential for markers capturing peripheral blood changes occurring in early prodromal $\mathrm{AD}$, as a high percentage of people with MCI who were expected to have a likely AD-endpoint displayed changes sufficiently different from normal to classify them as "AD-like" rather than as controls. The AD classifier appeared to make only a small distinction in favor of classifying MCI subjects who were close to receiving a diagnosis of $\mathrm{AD}$ as $\mathrm{AD}$ like than those who did not receive an AD diagnosis over the same short follow-up period of two years. This is in contrast to the performance of the imaging marker that classified far fewer MCI subjects overall as ADlike compared to the gene expression classifier, even those subjects who subsequently received an AD diagnosis within two years. This may suggest measures of structural brain changes have less sensitivity early in disease compared to the expression marker in blood we describe, but this will be uncertain until the MCI non-converters have been followed for a longer period. Changes detected by sMRI appear to occur at a later stage of disease than changes in $A \beta$ and tau $[11,12$, 87-89], and it will therefore be important in the future to evaluate our blood expression classifier alongside measures of CSF or brain A $\beta$ to see if the high classification of $\mathrm{AD}$ among the MCI subjects reflects early detection of prodromal disease and to map the dynamic onset of changes we observe.

Due to small sample numbers and therefore insufficient statistical power when we divided the MCI group in to those who subsequently received an AD diagnosis within two years and those who did not, we were unable to develop a classifier able to distinguish these two groups. However, the majority of MCI subjects had peripheral blood gene expression changes in common with $\mathrm{AD}$ patients including those who did and did not receive an AD diagnosis within two years. This is a finding we have previously observed in a study of cell based proteins in blood comparing $\mathrm{AD}$ and $\mathrm{MCI}$ subjects [23] and is similar to the profile of reduced $A \beta_{1-42}$ observed in the CSF in some control and many MCI subjects, which is believed to represent a pathophysiological process that significantly departs from normality [37]. Two factors are likely to contribute to this observation; first, around half of the subjects in the MCI cohort were selected for analysis because we knew they had subsequently converted to a probable AD diagnosis. Second, our MCI sample population are drawn from specialist memory clinics and are therefore more likely to represent people with established cognitive problems resulting from prodromal AD than might be expected from a cohort drawn from a community population, as we previously reported from a meta-analysis of longitudinal studies of MCI [90].

Alternatively, our blood expression marker may represent an endophenotype shared by a group of diseases with related etiology. Our two year follow-up period is insufficient to confirm which of the normal elderly control or $\mathrm{MCI}_{\mathrm{nc}}$ subjects have prodromal $\mathrm{AD}$ and will therefore eventually receive a clinical diagnosis of $\mathrm{AD}$. Pathological confirmation of an AD diagnosis will take longer still. We know of no existing studies with blood collected for RNA purposes where postmortem diag- 
nosis confirming AD would allow such analyses. While confirming the specificity of our marker is an important goal, the existence of an endophenotype, defined here as a disease-associated expression phenotype even though not necessarily specific to or present in all individuals still has clinical relevance. Such a marker can assist in the development of drugs targeting relevant and common disease endophenotypes and does not necessitate unique disease association to achieve efficacy in a relevant disease population. It could also be useful as part of a staged diagnostic approach, providing a cost effective method of identifying individuals with a greater likelihood of developing disease who could subsequently be referred for more expensive diagnostic tests.

Blood is emerging as a very promising tissue in which to achieve a non-invasive and relatively inexpensive assay for detection of $\mathrm{AD}$. In addition to changes in blood gene expression [31-33, 91], plasma protein panels have been described which accurately distinguish $\mathrm{AD}$ from normal elderly control people and/or MCI subjects who convert versus those who remain stable, or for predicting disease progression [92]. There are also many reports of individual proteins with altered abundance in AD plasma suggesting blood is a realistic tissue in which to identify markers of $\mathrm{AD}$ [23, 93-102]. However, there are still technical issues to overcome as not all protein measures reliably change across studies [103]. In the future, it will be important to explore the performance of different combinations of measures to achieve the most accurate biomarker for diagnosis and compare blood markers with more established biomarkers linked to pathophysiology and establish relative temporal patterns of change during disease progression across different biomarker modalities.

In conclusion, we have shown that peripheral blood shows promise as an AD-associated diagnostic blood gene expression marker that may be useful very early in pre-clinical disease. It performed similarly to using neuroimaging measures alone in $\mathrm{AD}$ and normal elderly control samples. Future work will evaluate this blood expression marker in subjects from which CSF measures of $A \beta_{1-42}$ and/or PET amyloid have been measured in order to further explore the specificity and timing of these changes. The existence of such a marker in an accessible tissue such as blood would contribute significantly toward efforts to identify and treat people with $\mathrm{AD}$ very early in their disease before significant neuronal loss has occurred. For example, CSF $A \beta_{1-42}$ and tau measurements to enrich for likely $\mathrm{AD}$ are predicted to reduce sample size by $67 \%$ and costs by $60 \%$ in a clinical trial compared to a trial with unselected MCI subjects [104]. Evaluation of the marker in related diseases will establish whether the changes we see are specific to AD or are shared across similar diseases. A lack of disease specificity would not diminish the value of a marker able to capture a common disease-associated endophenotype for which a specific treatment with real clinical value could be developed.

\section{ACKNOWLEDGMENTS}

We thank Rufina Leung, Megan Pritchard, Belinda Martin, Kathryn Lord, Nicola Dunlop, and Catherine Tunnard for sample collection and neuropsychiatric assessments of the London cohort. We thank all participants and their families. This work was supported by InnoMed (Innovative Medicines in Europe), an Integrated Project funded by the European Union of the Sixth Framework program priority FP6-2004LIFESCIHEALTH-5, Alzheimer's Research UK, The John and Lucille van Geest Foundation, the NIHR Biomedical Research Centre for Mental Health at the South London and Maudsley NHS Foundation Trust and Institute of Psychiatry Kings College London, and NIA/NIH RC1 grant 1RC1AG035610 (to GC).

Authors' disclosures available online (http://www.jalz.com/disclosures/view.php?id=1502).

\section{REFERENCES}

[1] Prince M, Jackson J (2009) Alzheimer's Disease International World Alzheimer Report. Alzheimer's Disease International, http://www.alz.co.uk/research/ files/WorldAlzheimerReport.pdf

[2] Dubois B, Feldman HH, Jacova C, Cummings JL, Dekosky ST, Barberger-Gateau P, Delacourte A, Frisoni G, Fox NC, Galasko D, Gauthier S, Hampel H, Jicha GA, Meguro K, O'Brien J, Pasquier F, Robert P, Rossor M, Salloway S, Sarazin M, de Souza LC, Stern Y, Visser PJ, Scheltens P (2010) Revising the definition of Alzheimer's disease: A new lexicon. Lancet Neurol 9, 1118-1127.

[3] Cummings JL (2010) Integrating ADNI results into Alzheimer's disease drug development programs. Neurobiol Aging 31, 1481-1492.

[4] Lovestone S, Thambisetty M (2009) Biomarkers for Alzheimer's disease trials - biomarkers for what? A discussion paper. J Nutr Health Aging 13, 334-336.

[5] Sampaio C (2009) Biomarkers in clinical trials of Alzheimer Disease (AD): What is expected from regulatory agencies? J Nutr Health Aging 13, 339-340.

[6] Furiak N, Klein R, Kahle-Wrobleski K, Siemers E, Sarpong E, Klein T (2010) Modeling screening, prevention, and delaying of Alzheimer's disease: An early-stage decision analytic model. BMC Med Inf Decis Making 10, article $24,1-24$. 
[7] Bancher C, Braak H, Fischer P, Jellinger KA (1993) Neuropathological staging of Alzheimer lesions and intellectual status in Alzheimer's and Parkinson's disease patients. Neurosci Lett 162, 179-182.

[8] Braak H, Braak E (1991) Neuropathological staging of Alzheimer-related changes. Acta Neuropathol (Berl) 82, 239-259.

[9] Amieva H, Le Goff M, Millet X, Orgogozo JM, Peres K, Barberger-Gateau P, Jacqmin-Gadda H, Dartigues JF (2008) Prodromal Alzheimer's disease: Successive emergence of the clinical symptoms. Ann Neurol 64, 492-498.

[10] Blennow K, de Leon MJ, Zetterberg H (2006) Alzheimer's disease. Lancet 368, 387-403.

[11] Jack CR, Knopman DS, Jagust WJ, Shaw LM, Aisen PS, Weiner MW, Petersen RC, Trojanowski JQ (2010) Hypothetical model of dynamic biomarkers of the Alzheimer's pathological cascade. Lancet Neurol 9, 119-128.

[12] Jack CR, Vemuri P, Wiste HJ, Weigand SD, Aisen PS, Trojanowski JQ, Shaw LM, Bernstein MA, Petersen RC, Weiner MW, Knopman DS (2011) Evidence for ordering of Alzheimer disease biomarkers. Arch Neurol 68, 15261535.

[13] Clark CM, Xie S, Chittams J, Ewbank D, Peskind E, Galasko D, Morris JC, McKeel DW, Farlow M, Weitlauf SL, Quinn J, Kaye J, Knopman D, Arai H, Doody RS, Decarli C, Leight S, Lee VMY, Trojanowski JQ (2003) Cerebrospinal fluid tau and beta-amyloid - How well do these biomarkers reflect autopsy-confirmed dementia diagnoses? Arch Neurol 60, 1696-1702.

[14] Strozyk D, Blennow K, White LR, Launer LJ (2003) CSF A beta 42 levels correlate with amyloid-neuropathology in a population-based autopsy study. Neurology 60, 652-656.

[15] Hertze J, Minthon L, Zetterberg H, Vanmechelen E, Blennow K, Hansson O (2010) Evaluation of CSF biomarkers as predictors of Alzheimer's disease: A clinical follow-up study of 4.7 years. J Alzheimers Dis 21, 1119-1128.

[16] Schoonenboom NSM, van der Flier WM, Blankenstein MA, Bouwman FH, Van Kamp GJ, Barkhof F, Scheltens P (2008) CSF and MRI markers independently contribute to the diagnosis of Alzheimer's disease. Neurobiol Aging 29, 669-675.

[17] Fagan AM (2006) Inverse relation between in vivo amyloid imaging load and CSF A[beta]42 in humans. Ann Neurol 59, 512-519.

[18] Grimmer T, Riemenschneider M, Forstl H, Henriksen G, Klunk WE, Mathis CA, Shiga T, Wester HJ, Kurz A, Drzezga A (2009) Beta amyloid in Alzheimer's disease: Increased deposition in brain is reflected in reduced concentration in cerebrospinal fluid. Biol Psychiatry 65, 927-934.

[19] Jagust WJ, Landau SM, Shaw LM, Trojanowski JQ, Koeppe RA, Reiman EM, Foster NL, Petersen RC, Weiner MW, Price JC, Mathis CA (2009) Relationships between biomarkers in aging and dementia. Neurology 73, 11931199.

[20] Tolboom N, van der Flier WM, Yaqub M, Boellaard R, Verwey NA, Blankenstein MA, Windhorst AD, Scheltens P, Lammertsma AA, van Berckel BNM (2009) Relationship of cerebrospinal fluid markers to $\mathrm{C}-11-\mathrm{PiB}$ and F-18-FDDNP binding. J Nucl Med 50, 1464-1470.

[21] Thambisetty M, Lovestone S (2010) Blood-based biomarkers of Alzheimer's disease: Challenging but feasible. Biomark Med 4, 65-79.

[22] Buerger K, Ernst A, Ewers M, Uspenskaya O, Omerovic M, Morgenthaler NG, Knauer K, Bergmann A, Hampel H (2009) Blood-based microcirculation markers in Alzheimer's disease-diagnostic value of midregional pro-atrial natriuretic peptide/C-terminal endothelin-1 precursor fragment ratio. Biol Psychiatry 65, 979-984.

[23] Hye A (2006) Proteome-based plasma biomarkers for Alzheimer's disease. Brain 129, 3042-3050.

[24] Hye A, Kerr F, Archer N, Foy C, Poppe M, Brown R, Hamilton G, Powell J, Anderton B, Lovestone S (2005) Glycogen synthase kinase- 3 is increased in white cells early in Alzheimer's disease. Neurosci Lett 373, 1-4.

[25] O’Bryant SE, Xiao G, Barber R, Reisch J, Doody R, Fairchild T, Adams P, Waring S, az-Arrastia R (2010) A serum protein-based algorithm for the detection of Alzheimer disease. Arch Neurol 67, 1077-1081.

[26] O'Bryant SE, Xiao G, Barber R, Reisch J, Hall J, Cullum C, Doody R, Fairchild T, Adams P, Wilhelmsen K, az-Arrastia R (2011) A blood-based algorithm for the detection of Alzheimer's disease. Dement Geriatr Cogn Disord 32, 55-62.

[27] Ray S, Britschgi M, Herbert C, Takeda-Uchimura Y, Boxer A, Blennow K, Friedman LF, Galasko DR, Jutel M, Karydas A, Kaye JA, Leszek J, Miller BL, Minthon L, Quinn JF, Rabinovici GD, Robinson WH, Sabbagh MN, So YT, Sparks D, Tabaton M, Tinklenberg J, Yesavage JA, Tibshirani R, Wyss-Coray T (2007) Classification and prediction of clinical Alzheimer's diagnosis based on plasma signaling proteins. Nat Med 13, 1359-1362.

[28] Schneider P, Hampel H, Buerger K (2009) Biological marker candidates of Alzheimer's disease in blood, plasma, and serum. CNS Neurosci Therap 15, 358-374.

[29] Thambisetty M, Hye A, Foy C, Daly E, Glover A, Cooper A, Simmons A, Murphy D, Lovestone S (2008) Proteomebased identification of plasma proteins associated with hippocampal metabolism in early Alzheimer's disease. J Neurol 255, 1712-1720.

[30] Thambisetty M, Simmons A, Velayudhan L, Hye A, Campbell J, Zhang Y, Wahlund L, Estman E, Kinsey A, Guentert A, Proitsi P, Causevic M, Killick R, Lunnon K, Lynham S, Broadstock M, Choudhry F, Howlett D, Williams R, Sharp S, Mitchelmore C, Tunnard C, Leung R, Foy C, O'Brien D, Breen G, Furney S, Kloszewska I, Mecocci P, Soinenen M, Tsolaki B, Vellas B, Hodges A, Murphy D, Parkins S, Richardson J, Ferucci L, Wong D, Zhou Y, Muehlboeck S, Evans A, Francis P, Spenger C, Lovestone S (2010) Association of plasma clusterin concentration with severity, pathology, and progression in Alzheimer disease. Arch Gen Psychiatry 67, 739-748.

[31] Booij BB, Lindahl T, Wetterberg P, Skaane NV, Sæbø S, Feten G, Rye PD, Kristiansen LI, Hagen N, Jensen M, Bårdsen K, Winblad B, Sharma P, Lönneborg A (2011) A gene expression pattern in blood for the early detection of Alzheimer's disease. J Alzheimers Dis 23, 109-119.

[32] Rye PD, Booij BB, Grave G, Lindahl T, Kristiansen L, Andersen HM, Horndalsveen PO, Nygaard HA, Naik M, Hoprekstad D, Wetterberg P, Nilsson C, Aarsland D, Sharma P, Lönneborg A (2011) A novel blood test for the early detection of Alzheimer's disease. J Alzheimers Dis 23, 121129.

[33] Fehlbaum-Beurdeley P, Prado ACJL, Pallares D, Carriere J, Soucaille C, Rouet F, Drouin D, Sol O, Jordan H, Wu DR, Lei L, Einstein R, Schweighoffer F, Bracco L (2010) Toward an Alzheimer's disease diagnosis via high-resolution blood gene expression. Alzheimers Dement 6, 25-38.

[34] Westman E, Simmons A, Muehlboeck JS, Mecocci P, Vellas B, Tsolaki M, Kloszewska I, Soininen H, Weiner MW, Lovestone S, Spenger C, Wahlund LO (2011) AddNeuroMed and ADNI: Similar patterns of Alzheimer's atrophy and 
automated MRI classification accuracy in Europe and North America. NeuroImage 58, 818-828.

[35] Fan Y, Batmanghelich N, Clark CM, Davatzikos C (2008) Spatial patterns of brain atrophy in MCI patients, identified via high-dimensional pattern classification, predict subsequent cognitive decline. NeuroImage 39, 1731-1743.

[36] Westman E, Simmons A, Zhang Y, Muehlboeck JS, Tunnard C, Liu Y, Collins L, Evans A, Mecocci P, Vellas B, Tsolaki M, Kloszewska I, Soininen H, Lovestone S, Spenger C, Wahlund LO (2011) Multivariate analysis of MRI data for Alzheimer's disease, mild cognitive impairment and healthy controls. NeuroImage 54, 1178-1187.

[37] Jack CR, Albert MS, Knopman DS, McKhann GM, Sperling RA, Carrillo MC, Thies B, Phelps CH (2011) Introduction to the recommendations from the National Institute on Aging-Alzheimer's Association workgroups on diagnostic guidelines for Alzheimer's disease. Alzheimers Dement 7, 257-262.

[38] Jicha GA, Parisi JE, Dickson DW, Johnson K, Cha R, Ivnik RJ, Tangalos EG, Boeve BF, Knopman DS, Braak H, Petersen RC (2006) Neuropathologic outcome of mild cognitive impairment following progression to clinical dementia. Arch Neurol 63, 674-681.

[39] Mitchell AJ, Shiri-Feshki M (2009) Rate of progression of mild cognitive impairment to dementia - meta-analysis of 41 robust inception cohort studies. Acta Psychiatr Scand 119, 252-265.

[40] Saxton J, Snitz BE, Lopez OL, Ives DG, Dunn LO, Fitzpatrick A (2009) Functional and cognitive criteria produce different rates of MCI. J Neurol Neurosurg Psychiatry 80, 737-743.

[41] Bennett DA, Wilson RS, Schneider JA, Evans DA, Beckett LA, Aggarwal NT, Barnes LL, Fox JH, Bach J (2002) Natural history of mild cognitive impairment in older persons. Neurology 59, 198-205.

[42] Decarli C (2003) Mild cognitive impairment: Prevalence, prognosis, aetiology, and treatment. Lancet Neurol 2, 15-21.

[43] Bennett DA, Schneider JA, Bienias JL, Evans DA, Wilson RS (2005) Mild cognitive impairment is related to Alzheimer disease pathology and cerebral infarctions. Neurology 64, 834-841.

[44] Petersen RC, Roberts RO, Knopman DS, Boeve BF, Geda YE, Ivnik RJ, Smith GE, Jack CR (2009) Mild cognitive impairment ten years later. Arch Neurol 66, 1447-1455.

[45] Schneider JA, Arvanitakis Z, Leurgans SE, Bennett DA (2009) The neuropathology of probable Alzheimer disease and mild cognitive impairment. Ann Neurol 66, 200-208.

[46] Lovestone S, Francis P, Strandgaard K, AddNeuroMed CG (2007) Biomarkers for disease modification trials - The innovative medicines initiative and AddNeuroMed. $J$ Nutr Health Aging 11, 359-361.

[47] Lovestone S, Francis P, Kloszewska I, Mecocci P, Simmons A, Soininen H, Spenger C, Tsolaki M, Vellas B, Wahlund L, Ward M (2009) AddNeuroMed-the European collaboration for the discovery of novel biomarkers for Alzheimer's disease. Ann N Y Acad Sci 1180, 36-46.

[48] Yesavage JA, Brink TL, Rose TL, Lum O, Huang V, Adey M, Leirer VO (1983) Development and validation of a geriatric depression screening scale - a preliminary-report. J Psychiatr Res 17, 37-49.

[49] McKhann G, Drachman D, Folstein M, Katzman R, Price D, Stadlan EM (1984) Clinical diagnosis of Alzheimer's disease: Report of the NINCDS-ADRDA Work Group under the auspices of Department of Health and Human Services Task Force on Alzheimer's Disease. Neurology 34, 939-944.
[50] American Psychiatric Association (2000) Diagnostic and statistical manual of mental disorders (IV-TR), 4th edition. Washington, DC

[51] Petersen RC, Smith GE, Waring SC, Ivnik RJ, Tangalos EG, Kokmen E (1999) Mild cognitive impairment: Clinical characterization and outcome. Arch Neurol 56, 303-308.

[52] Petersen RC, Doody R, Kurz A, Mohs RC, Morris JC, Rabins PV, Ritchie K, Rossor M, Thal L, Winblad B (2001) Current concepts in mild cognitive impairment. Arch Neurol 58, 1985-1992.

[53] Morris JC (1993) The Clinical Dementia Rating (CDR): Current version and scoring rules. Neurology 43, 2412-2414.

[54] Foy CML, Nicholas H, Hollingworth P, Boothby H, Willams J, Brown RG, Al-Sarraj S, Lovestone S (2007) Diagnosing Alzheimer's disease - non-clinicians and computerised algorithms together are as accurate as the best clinical practice. Int J Geriatr Psychiatry 22, 1154-1163.

[55] Folstein MF, Folstein SE, McHugh PR (1975) Mini-Mental State - practical method for grading cognitive state of patients for clinician. J Psychiatr Res 12, 189-198.

[56] Reisberg B, Ferris SH, Deleon MJ, Crook T (1988) Global Deterioration Scale (GDS). Psychopharmacol Bull 24, 661663.

[57] Welsh K, Butters N, Hughes J, Mohs R, Heyman A (1991) Detection of abnormal memory decline in mild cases of Alzheimer's disease using CERAD neuropsychological measures. Arch Neurol 48, 278-281.

[58] Du P, Kibbe WA, Lin SM (2008) lumi: A pipeline for processing Illumina microarray. Bioinformatics 24, 1547-1548.

[59] Simmons A, Westrnan E, Muehlboeck S, Mecocci P, Vellas B, Tsolaki M, Kloszewska I, Wahlund LO, Soininen H, Lovestone S, Evans A, Spenger C, AddNeuroMed C (2009) MRI measures of Alzheimer's disease and the AddNeuroMed Study. Biomarkers Brain Dis 1180, 47-55.

[60] Simmons A, Westman E, Muehlboeck S, Mecocci P, Vellas B, Tsolaki M, Kłoszewska I, Wahlund LO, Soininen H, Lovestone S, Evans A, Spenger C (2011) The AddNeuroMed framework for multi-centre MRI assessment of Alzheimer's disease: Experience from the first 24 months. Int J Geriatr Psychiatry 26, 75-82.

[61] Shi L, Campbell G, Jones WD, Campagne F, Wen Z, Walker SJ, Su Z, Chu TM, Goodsaid FM, Pusztai L, Shaughnessy JD, Oberthuer A, Thomas RS, Paules RS, Fielden M, Barlogie B, Chen W, Du P, Fischer M, Furlanello C, Gallas BD, Ge X, Megherbi DB, Symmans W, Wang MD, Zhang J, Bitter H, Brors B, Bushel PR, Bylesjo M, Chen M, Cheng J, Cheng J, Chou J, Davison TS, Delorenzi M, Deng Y, Devanarayan V, Dix DJ, Dopazo J, Dorff KC, Elloumi F, Fan J, Fan S, Fan X, Fang H, Gonzaludo N, Hess KR, Hong $\mathrm{H}$, Huan J, Irizarry RA, Judson R, Juraeva D, Lababidi S, Lambert CG, Li L, Li Y, Li Z, Lin SM, Liu G, Lobenhofer EK, Luo J, Luo W, McCall MN, Nikolsky Y, Pennello GA, Perkins RG, Philip R, Popovici V, Price ND, Qian F, Scherer A, Shi T, Shi W, Sung J, Thierry-Mieg D, Thierry-Mieg J, Thodima V, Trygg J, Vishnuvajjala L, Wang SJ, Wu J, Wu Y, Xie Q, Yousef WA, Zhang L, Zhang X, Zhong S, Zhou Y, Zhu S, Arasappan D, Bao W, Lucas AB, Berthold F, Brennan RJ, Buness A, Catalano JG, Chang C, Chen R, Cheng Y, Cui J, Czika W, Demichelis F, Deng X, Dosymbekov D, Eils R, Feng Y, Fostel J, Fulmer-Smentek S, Fuscoe JC, Gatto L, Ge W, Goldstein DR, Guo L, Halbert DN, Han J, Harris SC, Hatzis C, Herman D, Huang J, Jensen RV, Jiang R, Johnson CD, Jurman G, Kahlert Y, Khuder SA, Kohl M, Li J, Li L, Li M, Li QZ, Li S, Li Z, Liu J, Liu Y, Liu Z, Meng L, Madera M, Martinez-Murillo F, Medina I, Meehan 
J, Miclaus K, Moffitt RA, Montaner D, Mukherjee P, Mulligan GJ, Neville P, Nikolskaya T, Ning B, Page GP, Parker J, Parry R, Peng X, Peterson RL, Phan JH, Quanz B, Ren Y, Riccadonna S, Roter AH, Samuelson FW, Schumacher MM, Shambaugh JD, Shi Q, Shippy R, Si S, Smalter A, Sotiriou C, Soukup M, Staedtler F, Steiner G, Stokes TH, Sun Q, Tan PY, Tang R, Tezak Z, Thorn B, Tsyganova M, Turpaz Y, Vega SC, Visintainer R, von Frese J, Wang C, Wang E, Wang J, Wang W, Westermann F, Willey JC, Woods M, Wu S, Xiao N, Xu J, Xu L, Yang L, Zeng X, Zhang J, Zhang L, Zhang M, Zhao C, Puri RK, Scherf U, Tong W, Wolfinger RD (2010) The MicroArray Quality Control (MAQC)-IIII study of common practices for the development and validation of microarray-based predictive models. Nat Biotechnol 28, 827-838.

[62] Schwarz DF, Knig IR, Ziegler A (2010) On safari to Random Jungle: A fast implementation of Random Forests for highdimensional data. Bioinformatics 26, 1752-1758.

[63] Meng Y, Yu Y, Cupples LA, Farrer L, Lunetta K (2009) Performance of random forest when SNPs are in linkage disequilibrium. BMC Bioinformatics 10, 78.

[64] Blennow K (2004) Cerebrospinal fluid protein biomarkers for Alzheimer's disease. NeuroRx 1, 213-225.

[65] Johansson P, Mattsson N, Hansson O, Wallin A, Johansson JO, Andreasson U, Zetterberg H, Blennow K, Svensson J (2011) Cerebrospinal fluid biomarkers for Alzheimer's disease: Diagnostic performance in a homogeneous monocenter population. J Alzheimers Dis 24, 537-546.

[66] Mattsson N, Zetterberg H, Hansson O, Andreasen N, Parnetti L, Jonsson M, Herukka SK, van der Flier WM, Blankenstein MA, Ewers M, Rich K, Kaiser E, Verbeek M, Tsolaki M, Mulugeta E, Rosen E, Aarsland D, Visser PJ, Schroeder J, Marcusson J, de Leon M, Hampel H, Scheltens P, Pirttilae T, Wallin A, Jonhagen ME, Minthon L, Winblad B, Blennow K (2009) CSF biomarkers and incipient Alzheimer disease in patients with mild cognitive impairment. J Am Med Assoc 302, 385-393.

[67] Rabinovici GD, Jagust WJ (2009) Amyloid imaging in aging and dementia: Testing the amyloid hypothesis in vivo. Behav Neurol 21, 117-128.

[68] Visser PJ, Verhey F, Knol DL, Scheltens P, Wahlund LO, Freund-Levi Y, Tsolaki M, Minthon L, Wallin AK, Hampel H, Burger K, Pirttila T, Soininen H, Rikkert MO, Verbeek MM, Spiru L, Blennow K (2009) Prevalence and prognostic value of CSF markers of Alzheimer's disease pathology in patients with subjective cognitive impairment or mild cognitive impairment in the DESCRIPA study: A prospective cohort study. Lancet Neurol 8, 619-627.

[69] Aizenstein HJ, Nebes RD, Saxton JA, Price JC, Mathis CA, Tsopelas ND, Ziolko SK, James JA, Snitz BE, Houck PR, Bi WZ, Cohen AD, Lopresti BJ, DeKosky ST, Halligan EM, Klunk WE (2008) Frequent amyloid deposition without significant cognitive impairment among the elderly. Arch Neurol 65, 1509-1517.

[70] Bouwman FH, Schoonenboom NSM, Verwey NA, van Elk EJ, Kok A, Blankenstein MA, Scheltens P, van der Flier WM (2009) CSF biomarker levels in early and late onset Alzheimer's disease. Neurobiol Aging 30, 1895-1901.

[71] Hampel H, Shen Y, Walsh DM, Aisen P, Shaw LM, Zetterberg H, Trojanowski JQ, Blennow K (2010) Biological markers of amyloid beta-related mechanisms in Alzheimer's disease. Exp Neurol 223, 334-346.

[72] Hansson O, Zetterberg H, Buchhave P, Andreasson U, Londos E, Minthon L (2007) Prediction of Alzheimer's disease using the CSF Abeta42/Abeta40 ratio in patients with mild cognitive impairment. Dement Geriatr Cogn Disord 23, 316-320.

[73] Mintun MA (2006) [11C] PIB in a nondemented population: Potential antecedent marker of Alzheimer disease. Neurology 67, 446-452.

[74] Peskind ER, Li G, Shofer J, Quinn JF, Kaye JA, Clark CM, Farlow MR, Decarli C, Raskind MA, Schellenberg GD, Lee VMY, Galasko DR (2006) Age and apolipoprotein E*4 allele effects on cerebrospinal fluid beta-amyloid 42 in adults with normal cognition. Arch Neurol 63, 936-939.

[75] Shaw LM, Vanderstichele H, Knapik-Czajka M, Clark CM, Aisen PS, Petersen RC, Blennow K, Soares H, Simon A, Lewczuk P, Dean R, Siemers E, Potter W, Lee VM, Trojanowski JQ, Alzheimer's Disease Neuroimaging Initiative (2009) Cerebrospinal fluid biomarker signature in Alzheimer's disease neuroimaging initiative subjects. Ann Neurol 65, 403-413.

[76] Lunnon K, Ibrahim Z, Proitsi P, Lourdusamy A, Newhouse S, Sattlecker M, Furney S, Saleem M, Soinenen M, Kloszewska I, Mecocci P, Tsolaki B, Vellas B, Coppola G, Geschwind DH, Simmons A, Lovestone S, Dobson R, Hodges A, on behalf of the AddNeuroMed C (2012) Mitochondrial dysfunction and immune activation are detectable in early Alzheimer's disease blood. J Alzheimers Dis 30, 685-710.

[77] Ankarcrona M, Mangialasche F, Winblad B (2010) Rethinking Alzheimer's disease therapy: Are mitochondria the key? J Alzheimers Dis 20, S579-S590.

[78] Manczak M, Park BS, Lung YS, Reddy PH (2004) Differential expression of oxidative phosphorylation genes in patients with Alzheimer's disease - Implications for early mitochondrial dysfunction and oxidative damage. Neuromolecular Med 5, 147-162.

[79] Manczak M, Anekonda TS, Henson E, Park BS, Quinn J, Reddy PH (2006) Mitochondria are a direct site of A beta accumulation in Alzheimer's disease neurons: Implications for free radical generation and oxidative damage in disease progression. Hum Mol Genet 15, 1437-1449.

[80] Rhein V, Song XM, Wiesner A, Ittner LM, Baysang G, Meier F, Ozmen L, Bluethmann H, Drose S, Brandt U, Savaskan E, Czech C, Gotz J, Eckert A (2009) Amyloid-beta and tau synergistically impair the oxidative phosphorylation system in triple transgenic Alzheimer's disease mice. Proc Natl Acad Sci U S A 106, 20057-20062.

[81] Fox NC, Scahill RI, Crum WR, Rossor MN (1999) Correlation between rates of brain atrophy and cognitive decline in AD. Neurology 52, 1687-1689.

[82] Jack CR, Petersen RC, Obrien PC, Tangalos EG (1992) MR-based hippocampal volumetry in the diagnosis of Alzheimer's disease. Neurology 42, 183-188.

[83] Frisoni GB, Fox NC, Jack CR, Scheltens P, Thompson PM (2010) The clinical use of structural MRI in Alzheimer disease. Nat Rev Neurol 6, 67-77.

[84] Tapiola T, Alafuzoff I, Herukka SK, Parkkinen L, Hartikainen P, Soininen H, Pirttila T (2009) Cerebrospinal fluid beta-amyloid 42 and tau proteins as biomarkers of Alzheimer-type pathologic changes in the brain. Arch Neurol 66, 382-389.

[85] Wahlund LO, Blennow K (2003) Cerebrospinal fluid biomarkers for disease stage and intensity in cognitively impaired patients. Neurosci Lett 339, 99-102.

[86] Caroli A, Frisoni GB (2010) The dynamics of Alzheimer's disease biomarkers in the Alzheimer's Disease Neuroimaging Initiative cohort. Neurobiol Aging 31, 12631274. 
[87] Diniz BSO, Pinto JA, Forlenza OV (2008) Do CSF total tau, phosphorylated tau, and beta-amyloid 42 help to predict progression of mild cognitive impairment to Alzheimer's disease? A systematic review and meta-analysis of the literature. World J Biol Psychiatry 9, 172-182.

[88] Vemuri P, Wiste HJ, Weigand SD, Shaw LM, Trojanowski JQ, Weiner MW, Knopman DS, Petersen RC, Jack CR Jr, Alzheimer's Disease Neuroimaging, Initiative (2009) MRI and CSF biomarkers in normal, MCI, and AD subjects: Diagnostic discrimination and cognitive correlations. $\mathrm{Neu}$ rology 73, 287-293.

[89] Vemuri P, Wiste HJ, Weigand SD, Shaw LM, Trojanowski JQ, Weiner MW, Knopman DS, Petersen RC, Jack CR Jr, Alzheimer's Disease Neuroimaging, Initiative (2009) MRI and CSF biomarkers in normal, MCI, and AD subjects: Predicting future clinical change. Neurology 73, 294-301.

[90] Bruscoli M, Lovestone S (2004) Is MCI really just early dementia? A systematic review of conversion studies. Int Psychogeriatr 16, 129-140.

[91] Maes OC, Xu S, Yu B, Chertkow HM, Wang E, Schipper HM (2007) Transcriptional profiling of Alzheimer blood mononuclear cells by microarray. Neurobiol Aging 28, 1795 1809.

[92] Blennow K, Hampel H, Weiner M, Zetterberg H (2010) Cerebrospinal fluid and plasma biomarkers in Alzheimer disease. Nat Rev Neurol 6, 131-144.

[93] Angelopoulos P, Agouridaki H, Vaiopoulos H, Siskou E, Doutsou K, Costa V, Baloyiannis SI (2008) Cytokines in Alzheimer's disease and vascular dementia. Int J Neurosci 118, 1659-1672.

[94] Baranowska-Bik A, Bik W, Wolinska-Witort E, Martynska L, Chmielowska M, Barcikowska M, Baranowska B (2008) Plasma beta amyloid and cytokine profile in women with Alzheimer's disease. Neuroendocrinol Lett 29, 75-79.

[95] Bermejo P, Martin-Aragon S, Benedi J, Susin C, Felici E, Gil P, Ribera JM, Villar AM (2008) Peripheral levels of glutathione and protein oxidation as markers in the development of Alzheimer's disease from mild cognitive impairment. Free Radic Res 42, 162-170.
[96] Bermejo P, Martin-Aragon S, Benedi J, Susin C, Felici E, Gil P, Ribera JM, Villar AM (2008) Differences of peripheral inflammatory markers between mild cognitive impairment and Alzheimer's disease. Immunol Lett 117, 198-202.

[97] Desideri G, Cipollone F, Necozione S, Marini C, Lechiara MC, Taglieri G, Zuliani G, Fellin R, Mezzetti A, Di Orio F, Ferri C (2008) Enhanced soluble CD40 ligand and Alzheimer's disease: Evidence of a possible pathogenetic role. Neurobiol Aging 29, 348-356.

[98] Dik MG, Jonker C, Hack CE, Smit JH, Comijs HC, Eikelenboom P (2005) Serum inflammatory proteins and cognitive decline in older persons. Neurology 64, 1371-1377.

[99] Engelhart MJ, Geerlings MI, Meijer J, Kiliaan A, Ruitenberg A, van Swieten JC, Stijnen T, Hofman A, Witteman JCM, Breteler MMB (2004) Inflammatory proteins in plasma and the risk of dementia - The Rotterdam study. Arch Neurol 61, 668-672.

[100] Mocali A, Cedrola S, la Malva N, Bontempelli M, Mitidieri VAM, Bavazzano A, Comolli R, Paoletti F, La Porta CAM (2004) Increased plasma levels of soluble CD40, together with the decrease of TGF beta 1, as possible differential markers of Alzheimer disease. Exp Gerontol 39, 1555-1561.

[101] Schuitemaker A, Dik MG, Veerhuis R, Scheltens P, Schoonenboom NSM, Hack CE, Blankenstein MA, Jonker C (2009) Inflammatory markers in AD and MCI patients with different biomarker profiles. Neurobiol Aging 30, 18851889.

[102] Coppola G, Karyda A, Rademakers R, Wang Q, Baker M, Hutton M, Miller BL, Geschwind DH (2008) Gene expression study on peripheral blood identifies progranulin mutations. Ann Neurol 64, 92-96.

[103] Swardfager W, Lanctot K, Rothenburg L, Wong A, Cappell J, Herrmann N (2010) A meta-analysis of cytokines in Alzheimer's disease. Biol Psychiatry 68, 930-941.

[104] van Rossum IA, Vos S, Handels R, Visser PJ (2010) Biomarkers as predictors for conversion from mild cognitive impairment to Alzheimer-type dementia: Implications for trial design. J Alzheimers Dis 20, 881-891. 